\title{
THE BRITISH INSTITUTE OF PHILOSOPHICAL STUDIES
}

(Incorporated under the Companies Acts 1908-1917 as a Company not for Profit but limited by Guarantee.)

\section{President :}

Thi Rt. Hon. the Earl of Balfour, K.G., O.M., F.R.S.

Chairman of the Council:

Professor L. T. Hobhouse, M.A., D.LitT., LL.D., F.B.A.

Deputy Chairman of the Council:

A. D. Lindsay, C.B.E., M.A.

Chairman of the Executive Committee:

Sir Lynden Macassey, K.C., M.A., LL.D., D.Sc.

Director of Studies :

SYDNEY E. HOOPER, M.A.

Hon. Secretary :

P. M. Rossdale, LL.M.

Original Members of Council * :

Pror. S. Alexander, M.A., LL.D., D.Litt., F.B.A.

The Rt. HoN. Lord AsHField, P.C.

Major the hon. John J. Astor, M.P.

Llewelyn B. AtKinson, M.I.E.E. F. A. P. Aveling, M.C., Ph.D., D.Sc., D.D.

The RT. Hon. Stanley Baldwin, LL.D., D.L., M.P.

The RT. Rev. E. W. Barnes, M.A., Sc.D., F.R.S., F.R.A.S.

†F. C. BARTLEtT, M.A.

Sir Hugh BeLL, C.B., D.L., D.C.L., LL.D.

Sir Williay Berry, Bt.

Sir Williay BeVeridge, K.C.B., M.A., B.C.L., LL.D.

His Highness Prince Antoint Bibesco.

- By the Memorandum of Association, a member of Council on accepting lectureships with fees ipso facto ceases to be a member of the Council or Governing Body, and shall only be eligible for re-election after he shall have ceased to hold such office. This provision applies to those original members of Council whose names appear in the syllabus as lecturers for the Session 1927-28.

\section{† Members of the Executive Committee.}




\section{ORIGINAL MEMBERS OF COUNCIL}

A. S. Eddington, M.A., M.S.C., F.R.S.

Prof. Beatrice Edgell, M.A., Ph.D., D.Litt.

Sir Charles Ellis, K.C.B., G.B.E.

Prof. J. J. Findlay, M.A., M.Ed., Ph.D.

The Rr. Hon. H. A. L. Fisher, LL.D., D.Litt., F.B.A., F.R.S., M.P.

†E. Garcke, M.I.E.E. (Hon. Treasurer and Deputy Chairman of the Executive Committee).

The Rev. Alfred E. Garvie, M.A., D.D.

Prof. P. Geddes.

†M. Ginsberg, M.A., D.Litt.

Sir W. Guy Granet, G.B.E.

Commander Louis Greig, C.V.O., M.B., Ch.B.

Sir Robert A. Hadfield, Br., D.Sc., F.R.S.

Sir Henry Hadow, M.A., D.Mus., LL.D., F.R.S.I.

J. S. Hat.dane, M.A., LL.D., F.R.S.

C. R. S. HARRIS, M.A., D.Phil., Ph.D.

Sir Henry Head, F.R.S., M.D., LL.D.

Prof. H. J. W. Hetherington,M.A.

W. L. HicheNs, M.A.

†Prof. G. Dawes Hicks, M.A., Ph.D., Litt.D.

†PRor. L. T. HовноUsस, M.A., D.Litt., LL.D., F.B.A.

†John A. Hobson, M.A.

SIR JOSEPH HOOD, BT.

The RT. Hon. Sir Robert S. Horne, G.B.E., K.C., M.P.

†Prof. Julian S. HuXley, M.A.

The Very Rev. W. R. Inge, D.D., D.Litt.

The Rev. L. P. JAcks, M.A., LL.D., D.Litt.

†Prot. F. B. Jevons, M.A., Litt.D. The RT. Hon. SiR William JoynsonHicks, Br., D.L., M.P.

M. W. Keatinge, M.A., D.Sc.

J. N. KeYnes, Sc.D.

Prof. J. Laird, M.A.

SiR JOSFPh LaRMOR, Sc.D., D.Sc., LL.D., D.C.L., F.R.S.
†Prof. Harold J. Laski, M.A.

KenNeth Lee, LL.n.

†A. D. Lindsay, C.B.E., M.A.

†Sir Lynden Macassey, K.C., M.A., LL.D., D.Sc.

The Rt. Hon. J. Rausay MacDoNALD, LL.D., M.P.

Prof. John S. Mackenzie, M.A., Litt.D., LL.D.

Sir W. Leslie Mackenzie, M.A., M.D., LL.D.

The Rr. Hon. H. P. Macmillan, K.C., M.A., LL.D.

†H. CRIChton-Miller, M.A., M.D.

Prof. C. Lloyd Morgan, D.Sc., LL.D., F.R.S.

†PRoF. J. H. MUIRHEAd, M.A., LL.D.

Prof. Gilbert Murray, LL.D., D.Litt., F.B.A.

†Charles S. Myers, C.B.E., M.D., Sc.D., F.R.S.

The Hon. Sir Charles A. Parsons, K.C.B., M.A., LL.D., D.Sc., F.R.S.

Prof. T. H. Pear, M.A., B.Sc.

The RT. HoN. Lord EUSTace PerCy, M.A., M.P.

Sir William Plender, Bt., G.B.E., LL.D., D.L.

The RT. HoN. The MAster of THE ROLIS(LORDHANWORTH,K.B.E.).

Prof. Carveth Read, M.A.

L. Arnaud Reid, M.A., Ph.D.

The RT. HoN. The Viscountess RHONDDA.

The Rt. Hon. LoRd RIddell.

Prof. Williay Rothenstein, M.A., A.R.C.A.

The Hon. Bertrand Russell, M.A., F.R.S.

F. C. S. Schiller, M.A., D.Sc.

Prof. J. W. Scott, M.A., Ph.D.

A. F. Shand, M.A.

†Sir Chartes Sherrington, O.M., G.B.E., M.A., M.D., D.Sc., F.R.S.

tMay Sinclair.

†Sir Henry Slesser, K.C., M.P.

Prof. J. A. Surth, M.A., LL.D.

General The Rt. Hon. J. C. Smuts, P.C., K.C., C.H., M.L.A.

Prof. W. R. SORLEY, Litt.D., LL.D., F.B.A. 
†Prof. C. Spearman, Ph.D., F.R.S. Prof. J. Arthur Thouson, M.A.,

$\nmid$ L. Susan Stebbing, M.A. LL.D.

Prof. J. L. Stocks, D.S.O., M.A.

Sir EDWin F. Stockton.

Sir Oswald Stoll.

Prof. G. F. Srout, M.A., LL.D., F.B.A.

Prof. C. A. Strong, LL.D.

H. Sturt, M.A.

A. A. Campeell Swinton, F.R.S. Pror. A. E. TAYLOR, M.A., D.Litt., F.B.A.

The Rr. Rev. William Temple, M.A., D.Litt., D.D.

fPror. F. W. Thomas, M.A., Ph.D.

Prof. D'ARCY WhNTworth ThompsoN, C.B., D.Litt., F.R.S.

Sir J. J. Thomson, O.M., D.Sc., LL.D., F.R.S.

The Rev. Leslie J. Walker, S.J., M.A.

Prot. Clement C. J. WebB, M.A., LL.D.

SIR R. L. WEDGEWOOD, C.B., C.M.G.

Prof. E. A. Westermarck, Ph.D., LL.D.

JaMres Martin White, J.P., F.R.S.E.

DOROTHY WrINCH, D.Sc.

Sir Altred F. YarRow, Br., F.R.S.

\section{OBJECTS OF THE INSTITUTE}

The British Institute of Philosophical Studies exists to bring leading exponents of various branches of Philosophy into direct contact with the general public, with the purpose of satisfying a need felt by many men and women in every walk of life for greater clearness and comprehensiveness of vision in human affairs.

With this broad educational purpose in view, the Institute-

(1) Provides at suitable times in the day and evening courses of lectures by leading exponents in the more important subjects coming within the scope of Philosophy. All branches of Philosophy are represented-Ethics and Social Philosophy, the Philosophy of Law and of the Sciences, of the Fine Arts and of Religion, as well as Logic and Metaphysics and Psychology.

(2) Issues a quarterly philosophical Journal (free to members).

(3) Proposes to form a philosophical Library.

(4) Gives guidance and assistance to individuals in their philosophical reading.

(5) Encourages research in Philosophy.

Those desirous of becoming members of the Institute are invited to apply for further particulars and forms of application to the Director of Studies, 88 Kingsway, London, W.C. 2.

$\dagger$ Members of the Executive Committec. 